\title{
Dosimetric Evaluation of Adaptive Therapy in Non-Small Cell Lung Cancer Patients Undergoing Palliative Thoracic Radiotherapy
}

\author{
Evrim DUMAN ${ }^{1}$, Yigit CECEN ${ }^{2}$, Bora SINDIR ${ }^{2}$, Beyza OZDEMIR $^{2}$, Mustafa YILDIRIM ${ }^{3}$, \\ Sare CECEN ${ }^{1}$, Berrin PEHLIVAN ${ }^{4}$, Melek Nur YAVUZ ${ }^{2}$ \\ ${ }^{1}$ Antalya Training and Research Hospital, Department of Radiation Oncology, Antalya \\ ${ }^{2}$ Akdeniz University Faculty of Medicine, Department of Radiation Oncology, Antalya \\ ${ }^{3}$ Medical Park Gaziantep Hospital, Department of Medical Oncology, Gaziantep \\ ${ }^{4}$ Medical Park Istanbul Bahcelievler Hospital, Department of Radiation Oncology, Istanbul, TURKEY
}

\begin{abstract}
This study aimed to describe changes in gross tumour volume (GTV) that occurred during the course of radiotherapy (RT) in patients who underwent palliative thoracic radiotherapy (PTR), and to describe the role of adaptive treatment for protection of normal tissue. Twenty patients with non-small cell lung cancer (NSCLC) referred for PTR were treated using a total of 10 fractions and a dose of 300 cGy/day in accordance with the initial GTV, clinical target volume (CTV), and planning target volume (PTV). Computed tomography simulation (CTS) images were retaken for each patient at the end of the fifth fraction, and the second plan was created. The fractional volume reduction (FVR) of the GTV and the PTV were then calculated. The changes in normal tissue dose-volume histogram (DVH) parameters between the two plans were compared. Mean GTV and PTV values were $223.9 \mathrm{cc}$ and $1113.3 \mathrm{cc}$ for the first plan and $196.2 \mathrm{cc}$ and $1029.7 \mathrm{cc}$ for the second plan, respectively. After five fractionated treatments, the FVR was $15.9 \%$ of the GTV ( $p<$ $0.001)$ and $8 \%$ of the PTV $(p<0.001)$. The daily regression for GTV was 3.1 percent. A statistically non-significant decrease occurred for the normal tissue doses. The geometric changes in GTV and PTV positively influenced the DVH parameters, but were not statistically significant. The clinical implications of this approach to CTS plan assessment should be examined using prospective studies with adequate number of patients.
\end{abstract}

Keywords: Non-small cell lung cancer, Adaptive radiotherapy, Palliative radiotherapy

\section{ÖZET}

Palyatif Torasik Radyoterapi Uygulanan Küçük Hücreli Dişi Akciğer Kanseri Hastalarinda Adaptif Tedavinin Dozimetrik Değerlendirmesi

Bu çallşmada palyatif torasik radyoterapi uygulanan hastalarda radyoterapi süresince gözlenen görüntülenebilir tümör hacim (GTV) değişikliklerini ve normal doku korumadaki rolünü göstermek amaçlanmıştır. Palyatif torasik radyoterapi planlanan küçük hücreli dişı akciğer kanseri (KHDAK) tanilı 20 hasta, bașlangıçtaki GTV, klinik hedef hacim (CTV) ve planlanan tedavi hacmine (PTV) göre yapilan planlama ile 300 cGy/gün ile toplam 10 fraksiyonda tedavi edilmiștir. Beșinci fraksiyon sonunda hastaların bilgisayarlı tomografi simülatör (BTS) görüntüleri tekrarlanmıș ve yeniden GTV, CTV, PTV ve normal dokular tanımlanarak ikinci planlamalar yapıımıștır. Beșinci fraksiyondaki GTV ve PTV' de fraksiyone hacim azalması (FHA) hesaplanmış ve her iki planlama arasında normal doku doz-hacim histogramı (DVH) parametrelerindeki değișimler incelenmiştir. llk planda ortalama GTV ve PTV değerleri sırasılla $223.9 \mathrm{cc}$ ve $1113.3 \mathrm{cc}$, 2. planda ise sirasiyla 196.2cc ve 1029.7cc olarak bulunmuștur. Beș fraksiyon tedavi sonrasında GTV' de FHA \%15.9 ( $p<0.001)$, PTV' de ise \%8 ( $p<0.001)$ olarak hesaplanmış, GTV için günlük regresyon oranı \%3.1 olarak bulunmuștur. Normal dokuların dozları incelendiğinde ortalama kalp, özefagus, akciğer ve maksimum medulla spinalis dozlarnnda istatistiksel anlamllığa ulaşmayan azalma tespit edilmiștir. Bu çalışmada radyoterapi süresince tekrarlanan BTS görüntülerinde GTV ve PTV' de gözlenen geometrik değişiklikler DVH parametrelerini olumlu yönde etkilemiş olmasına rağmen istatistiksel anlamlı düzeye ulaşamamıștır. BTS planlamaları üzerinden yapılan bu değerlendirmemizin klinik yansımalarııı prospektif ve daha fazla hasta sayllı çalışmalarla yapıımasına intiyaç vardır.

Anahtar Kelimeler: Küçük hücreli dıșı akciğer kanseri, Adaptif radyoterapi, Palyatif radyoterapi 


\section{INTRODUCTION}

Lung cancer accounts for $13 \%$ of all cancer patients and $18 \%$ of cancer deaths worldwide. Lung cancer was previously classified into two groups, small cell lung cancer (SCLC) and non-small cell lung cancer (NSCLC). To aid in choosing effective systemic therapy, NSCLC is also currently divided into the subtypes adenocarcinoma, squamous cell carcinoma, and large cell carcinoma. ${ }^{1}$

NSCLC accounts for more than $85 \%$ of all lung cancer cases. Approximately $75-85 \%$ of patients have advanced disease. The mean survival time of these patients is 6 to 9 months. Palliative thoracic radiotherapy (PTR) is applied to most of these patients for the palliation of intrathoracic symptoms (e.g., cough, haemoptysis, dyspnoea, and chest pain). Palliation is provided at least $50 \%$ of the survival time, but the palliation level of each symptom differs. Haemoptysis and chest pain response to PTR are greater, compared with the other symptoms. ${ }^{2-5}$

The goal for patients who are referred for PTR should be optimal control, acceptable treatment toxicity, limitation of treatment time, and avoidance of hospitalization. It is unclear, however, which fractionation scheme offers the best response and the lowest toxicity. The result of previous studies indicated that short fractionation scheme PTR (e.g., $10 \mathrm{~Gy} / 1 \mathrm{f}, 16-17 \mathrm{~Gy} / 2 \mathrm{f}$, and $20 \mathrm{~Gy} / 5 \mathrm{f}$ ) results in good symptomatic improvement in patients with thoracic symptoms and who, in general, have a poor performance status. The short fractionation schemes for patients who receive palliative systemic treatment for recently initiated thoracic symptoms are inserted between chemotherapy cures to ensure that patients can continue treatment without interruption. Longer fractionation schemes, such as $36 \mathrm{~Gy} / 12 \mathrm{f}$, are recommended for patients who are in a generally good performance status because there is a survival benefit in spite of the disadvantages associated with the increased toxicity risks and extended treatment times. There is currently no specific long fractionation scheme that provides maximum survival and symptom palliation with minimal toxicity. ${ }^{6,7}$
Adaptive radiotherapy is defined as the renewal of the treatment plan during radiotherapy (RT). It incorporates the changes in tumour volume, shape, and position revealed by weekly computed tomography simulation (CTS) images. ${ }^{8}$ The results of several studies that evaluated adaptive treatment for locally advanced-stage NSCLC have been published. Tumour volume decreases during definitive RT in patients diagnosed with locally advancedstage NSCLC. Kupelin, et al. reported a daily tumour volume reduction of $1.2 \%(0.6 \%-2.3 \%)$ in 10 patients. ${ }^{9}$ During treatment, safe dose distribution can be achieved via customization of field size and treatment dose for each patient in accordance with gross tumour volume (GTV) reduction..$^{10}$ Ramsey et al. found a mean GTV reduction of $31 \%(21 \%$ $41 \%$ ) during adaptive treatment compared with non-adaptive treatment. The ipsilateral lung volume receiving over 20Gy decreases $21 \%$ (17\%$23 \%)$ and there is $17 \%(11 \%-24 \%)$ less reduction in lung perfusion. ${ }^{11} \mathrm{RT}$ outcomes can be improved by systematic evaluation of treatment variations and re-optimization of the treatment plan during adaptive treatment. ${ }^{10}$

The objectives of this study were to examine the extent of change in GTV during PTR. Tumour volume and localization changes, external contour changes (e.g., weight loss) and presence of atelectasis, and the effects of volume changes on treatment quality and on the total treatment plan (i.e., initial and new plan) were included in the assessment.

\section{PATIENTS AND METHODS}

We evaluated retrospective computerized RT planning data (1 June 2010 - 30 April 2011) from 20 patients diagnosed with NSCLC, and treated using PTR (Akdeniz University Faculty of Medicine, Department of Radiation Oncology, Antalya, Turkey). The study was approved by the institutional ethics committee.

\section{Patient Characteristics}

The mean patient age was 61 (range, 50-82); the NSCLC stages were identified as IIIB and IV ac- 


\begin{tabular}{|c|c|c|}
\hline & Plan I & Plan II \\
\hline Number of patients & 20 & 20 \\
\hline CT & Pretreatment & Pretreatment and after 5 th fraction \\
\hline Fraction ( $f)$ & 10 & $5+5$ \\
\hline \multirow[t]{2}{*}{ GTV } & $\operatorname{GTV} 1(10 \mathrm{f})$ & GTV1 (5 f) \\
\hline & & GTV2 (5 f) \\
\hline \multirow[t]{2}{*}{ PTV } & PTV1= CTV1 + 10-15 mm (10 f) & PTV1 (5 f) \\
\hline & & PTV2= CTV2 $+10-15$ mm (5 f) \\
\hline Treatment plan \& DVH & $\begin{array}{l}\text { Single treatment plan and DVH } \\
\text { evaluation with pretreatment CT images }\end{array}$ & $\begin{array}{l}\text { Combined treatment plan and DVH evaluation with } \\
\text { pretreatment and after } 5 \text { fraction CT images }\end{array}$ \\
\hline
\end{tabular}

cording to the tumour, node, and metastasis (TNM) staging system. Eastern Cooperative Oncology Group (ECOG) performance status before RT was between 1 and 3. Seven (35\%) patients (stage IIIB disease) who were not suitable candidates for definitive treatment due to low performance status and comorbid disease were referred for PTR. The remaining $13(65 \%)$ patients (stage IV disease) were also initially treated using PTR.

\section{Radiotherapy}

For planning the RT, CTS images of the patients were taken (adjacent axial slice spacing $2.5 \mathrm{~mm}$; GE-Lightspeed64® computed tomography simulator, GE, Fairfield, USA) while their hands were placed on their heads. The entire thorax, from the apex to the diaphragm, was included in each image. Diagnostic computed tomography (CT) thoracic images were also taken of the 13 patients with stage IV disease to identify target volume. Additional positron emission tomography (PETCT) was used for the other seven patients. The tumour volume, which included the primary tumour and the mediastinal lymph nodes, was contoured as GTV. To determine the clinical target volume (CTV), $7 \mathrm{~mm}$ was added to the GTV. The planning target volume (PTV) was obtained by adding 15 $\mathrm{mm}$ in the superior-inferior direction, and $10 \mathrm{~mm}$ for the right-left and anterior-posterior directions to the CTV. To determine the treatment volume, an extra margin of $10 \mathrm{~mm}$ was added to the PTV.
The oesophagus, heart, lung, and medulla spinalis volumes were also determined. The isocentre was located to the centre of the PTV using RT planning software (Precise, ELEKTA ${ }^{\circledR}$, Stockholm, Sweden). The RT was planned to ensure that the prescribed dose distribution was \pm 5 percent. A total of 3000 cGy RT was planned (10 fractions, daily fractional dose of $300 \mathrm{cGy}$, mean PTV dose of 3098 cGy [3008 cGy-3197 cGy]). Three-dimensional conformal RT was scheduled for each patient. Patients were treated with a linear accelerator (ELEKTA ${ }^{\circledR}$, Synergy Platform, West Sussex, UK) using $10 \mathrm{MV}$ photon beams.

The study examined the tumour volume dependent changes in dose-volume parameters for the patients, for whom new plans were developed for the last five fractions of the treatment. CTS images were retaken of each patient after the fifth treatment fraction. The same doctor again identified GTV, CTV, PTV, and normal tissue volumes of the oesophagus, heart, medulla spinalis, and both lungs.

Two groups of plans were developed to compare tumour volume changes and dose-volume histogram (DVH) parameters (Table 1). For the first plan, the CTS images that were taken before treatment were used for every patient. GTV1, CTV1, PTV1, and normal tissues were identified. The treatment was planned as 30Gy/10f, with the isocentre in the centre of PTV1. DVH parameters were recorded for the first plan. For the second plan, GTV2, CTV2, 

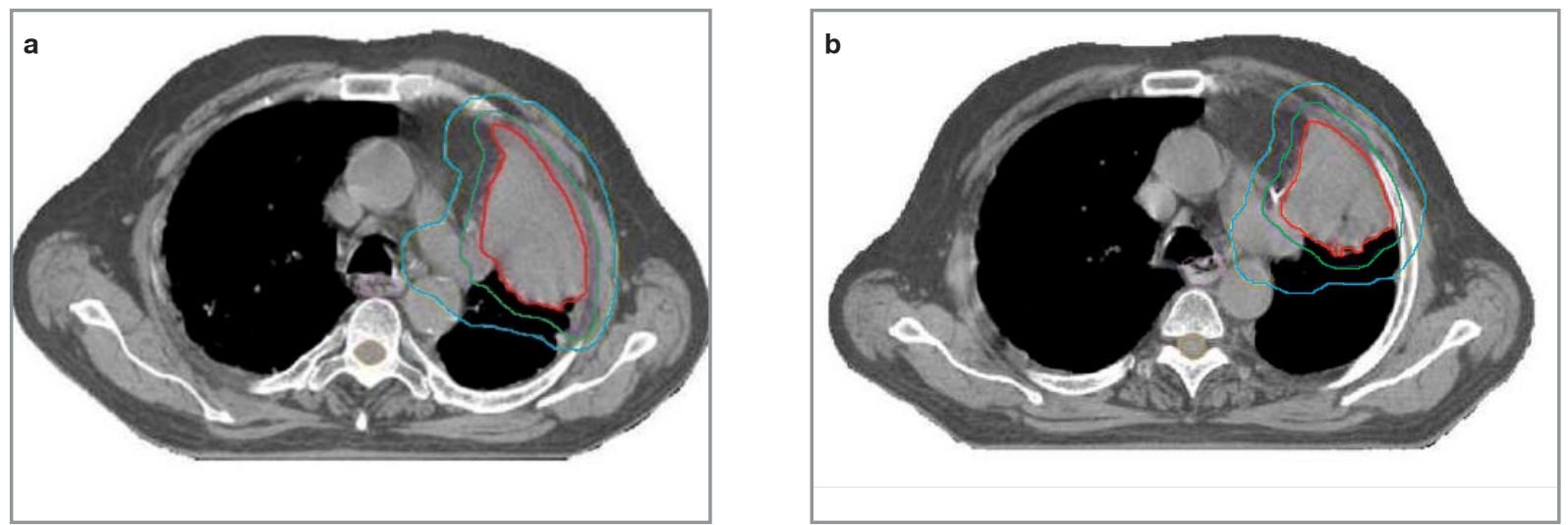

Figure 1. Gross tumour volume (red line), clinical target volume (green line), and planning target volume (blue line) defined in the axial section in computed tomography simulation images of the same patient before treatment (a) and after the fifth fraction (b).

PTV2, and normal tissues were identified in the CTS images of each patient, taken after the fifth fraction (Figure 1). A treatment plan using a total of $30 \mathrm{~Gy} / 10 \mathrm{f}$ was developed in two stages. It included the first five fractions using the CTS images (isocentre in the PTV1 centre) and the last five fractions using the CTS images taken after the fifth fraction (isocentre in the centre of PTV2).

Each patient's DVHs associated with the first and second RT plans were assessed separately. For normal lung tissue, the PTV was subtracted from the whole lung volume, and the mean lung dose was estimated using the remaining volume. The lengths of the medulla spinalis and oesophagus, their mean and maximum doses, and the mean dose for the heart, were calculated.

The fractional volume reduction (FVR) in GTV and PTV in the fifth fraction was calculated using: $\mathrm{FVR}=100 \times(\mathrm{V} 1-\mathrm{V} 2) / \mathrm{V} 1(\mathrm{~V} 1=$ volume before treatment, $\mathrm{V} 2=$ volume in the fifth fraction). The GTV daily regression rate was calculated as a ratio of fractional volume reduction to treatment duration.

\section{Statistical Analysis}

The paired sample $t$ test was used to determine the significance of the tumour volume changes in the repeated CTS images. The unpaired sample t test was used to compare differences in tumour volumes and DVH parameters between the adaptive and non-adaptive planning groups.

\section{RESULTS}

The 20 patients who were diagnosed with NSCLC and treated with PTR were assessed. The CTS images taken before treatment and after the fifth fraction were taken at a 9-day interval.

\section{Volumetric Assessment}

The results for the first plan indicated that the mean GTV values were $223.9 \mathrm{cc}(22.5-747.4 \mathrm{cc})$ before, and $196.2 \mathrm{cc}(13.8-742.9 \mathrm{cc}, \mathrm{p}<0.001)$ after the five-fraction treatment. The mean PTV values were $1113.3 \mathrm{cc}(306.8$ - $2561.2 \mathrm{cc})$ before, and $1029.7 \mathrm{cc}$ $(274.9-2507.5 \mathrm{cc})$ after the fifth fraction. The fractional volume reduction was $15.9 \%(7.7-41.5$; $\mathrm{p}<$ $0.001)$ for GTV and $8 \%(1.4-27.9 ; \mathrm{p}<0.001)$ for PTV (Table 2). The GTV daily regression rate was $3.1 \%$, calculated as a ratio of fractional volume reduction to treatment duration.

The results for the first plan also indicated that the mean field size was $261 \mathrm{~cm}^{2}\left(110-478.6 \mathrm{~cm}^{2}\right)$ before, and $245.2 \mathrm{~cm}^{2}\left(106.8-483 \mathrm{~cm}^{2}\right)$ after, the fifth fraction. The mean reduction in field size was $5 \%(1.7-21.7 ; \mathrm{p}=0.003)$.

The mean oesophagus length measured in the treatment field was $12.9 \mathrm{~cm}(4.2-21.9 \mathrm{~cm})$ for the first plan, and $12.9 \mathrm{~cm}(2.5-20.8 \mathrm{~cm})$ for the second plan. The mean medulla spinalis length was 11.7 $\mathrm{cm}(1.0-22.9 \mathrm{~cm})$ for the first plan, and $11.2 \mathrm{~cm}$ $(0.5-22.2 \mathrm{~cm})$ for the second plan. There were differences between the two plans in terms of the lengths of the oesophagus and medulla spinalis. 
International Journal of Hematology and Oncology

Table 2. Volumetric assessment of gross tumour volume (GTV), planning target volume (PTV), and field size.

\begin{tabular}{|lllll|}
\hline & Plan I & Plan II & Reduction (\%) & p value \\
\hline \multirow{2}{*}{ GTV } & $223.9 \mathrm{cC}$ & $196.2 \mathrm{cc}$ & 15.9 & $<0.001$ \\
& $(22.5-747.4 \mathrm{cc})$ & $(13.8-742.9 \mathrm{cc})$ & & $<0.001$ \\
PTV & $1113.3 \mathrm{cc}$ & $1029.7 \mathrm{cc}$ & 8 & 0.003 \\
& $(306.8-2561.2 \mathrm{cc})$ & $(274.9-2507.5 \mathrm{cc})$ & & \\
\hline \multirow{2}{*}{ Field Size } & $261 \mathrm{~cm} 2$ & $254.2 \mathrm{~cm} 2$ & 5 & \\
& $\left(110-478.6 \mathrm{~cm}^{2}\right)$ & $\left(106.8-483 \mathrm{~cm}^{2}\right)$ & & \\
& & &
\end{tabular}

\section{Dosimetric Assessment}

The results for the doses for the normal tissues indicated that the mean heart, the mean oesophagus, the mean lung, and the maximum medulla spinalis, doses all decreased. The result for the dosimetric values for the heart, oesophagus, lung, and medulla spinalis are presented in Table 3.

The results for the dosimetric data for the normal tissues indicated that the decreases in maximum mean doses were $3.3 \%(-14.9 \%-17 \%$; $\mathrm{p}=$ $0.077)$ for the heart, $1.35 \%(-28.5 \%-23.5 \%$; $=$ $0.599)$ for the oesophagus, $2.9 \%(-18.5 \%-52 \%$; $\mathrm{p}=0.336)$ for the lung, and $1.2 \%(-36.6 \%-23.4 \%$; $\mathrm{p}=0.630)$ for the medulla spinalis (dmax) doses. These findings were not statistically significant.

\section{DISCUSSION}

PTR is used for most stage III NSCLC patients who have poor prognostic factors for the palliation of intrathoracic symptoms (e.g., cough, haemoptysis, dyspnoea, and chest pain). PTR is also used to treat patients with stage IV NSCLC. There is currently no consensus regarding the fractionation scheme that should be used for the most effective, minimally toxic, treatment.

Using a randomized study design, Erridge et al. compared the 30Gy/10f and 10Gy/1f treatment schedules in 148 patients (12). The median survival times were 28.3 and 22.7 weeks $(p=0.197)$, respectively. The longer fractionation scheme did not provide a statistically significant survival ad-

\begin{tabular}{|c|c|c|c|c|c|}
\hline & $\begin{array}{l}\text { Minimum } \\
\text { (cGy) }\end{array}$ & $\begin{array}{l}\text { Maximum } \\
\text { (cGy) }\end{array}$ & $\begin{array}{l}\text { Mean } \\
\text { (cGy) }\end{array}$ & $\begin{array}{l}\text { Reduction } \\
(\%)\end{array}$ & $p$ value \\
\hline \multicolumn{6}{|l|}{ Heart } \\
\hline Plan I & 15 & 2603 & 1156 & & \\
\hline Plan II & 15 & 2556 & 1113 & 3,3 & 0.07 \\
\hline \multicolumn{6}{|c|}{ Oesophagus } \\
\hline Plan I & 232 & 2681 & 1566 & & \\
\hline Plan II & 247 & 2574 & 1543 & 1.3 & 0.59 \\
\hline \multicolumn{6}{|l|}{ Lung } \\
\hline Plan I & 251 & 1922 & 770 & & \\
\hline Plan II & 251 & 1016 & 715 & 2.9 & 0.33 \\
\hline \multicolumn{6}{|c|}{ Medulla Spinalis } \\
\hline Plan I & 830 & 3390 & 2769 & & \\
\hline Plan II & 675 & 3338 & 2764 & 1.2 & 0.63 \\
\hline
\end{tabular}


vantage and deterioration in dyspnoea was frequent. However, levels of anxiety declined in this group after treatment, there was overall greater general improvement, and there was a statistically significant palliative effect on chest pain. The treatment-based morbidity rates were similar between groups.

Kramer et al. randomly assigned 297 symptomatic patients (stage III and IV with poor performance or loss of weight) to $30 \mathrm{~Gy} / 10$ f or $16 \mathrm{~Gy} / 2 \mathrm{f}$ treatment groups. ${ }^{13}$ The one-year survival rate was greater in the $30 \mathrm{~Gy} / 10$ froup ( $19.6 \%$ vs. $10.9 \%, \mathrm{p}=0.03$ ). The palliation effect was also significantly longer $(p<0.001)$. The subgroup analyses revealed that this advantage was experienced by the patients who had a generally good performance status. Symptom palliation and treatment-based toxicity rates were similar in both groups.

In our clinic, the $30 \mathrm{~Gy} / 10 \mathrm{f}$ treatment is applied to patients with good performance because it has survival benefits. This treatment is given in accordance with the guidelines of the palliative thoracic RT clinical application manual of the American Society for Radiation Oncology (ASTRO). ${ }^{7}$ The $16 \mathrm{~Gy} / 2 \mathrm{f}$ treatment is applied to patients with poor performance to obtain similar symptom palliation outcomes.

Adaptive RT is one of the methods used for NSCLC patients being treated curatively. This method results in decreased toxicity to normal tissue and allows for an increased tumour dose. To the best of our knowledge, no studies have been published on the applicability of adaptive RT to patients who are treated for palliation.

In a study performed by Yan et al. to identify the between-fraction changes, the investigators predicted, based on repeated imaging during the course of treatment, that PTV margin size could be reduced. ${ }^{14}$ They suggested that this method could be the most effective option for adaptive control. They also suggested that RT accuracy could be improved by using adaptive planning to correct systemic set-up errors. In our study, the RT plans of our patients were renewed based on CTS images taken during the fifth treatment fraction.

\begin{tabular}{|lll|}
\hline \multicolumn{3}{|l|}{$\begin{array}{l}\text { Table 4. Daily regression ratios for adaptive radiotherapy se- } \\
\text { ries from lung cancers }{ }^{17} \text {, compared } \\
\text { current study. }\end{array}$} \\
\hline & $\begin{array}{l}\text { Number } \\
\text { of patients }\end{array}$ & $\begin{array}{l}\text { Daily regression } \\
\text { (\%) }\end{array}$ \\
\hline Erridge et al. & 25 & 0.9 \\
Kupelian et al. & 10 & 1.2 \\
Siker et al. & 25 & 2.4 \\
Bosmans et al. & 23 & 0.39 \\
Underberg et al. & 40 & 1.4 \\
Britton et al. & 8 & 1.3 \\
Woodford et al. & 17 & 0.79 \\
Van Zwienen et al. & 114 & 0.6 \\
Fox et al. & 22 & 1.2 \\
Feng et al. & 14 & 1.4 \\
Current study & 20 & 3.1 \\
\hline
\end{tabular}

The results of a study of 114 NSCLC patients indicated that tumour volume decreased in only $40 \%$ of the patients and that the rate of daily regression was $0.6 \% .{ }^{15} \mathrm{~A}$ study on daily volume decrease was also performed by investigators from the Johns Hopkins Hospital. ${ }^{16}$ CTS images were retaken twice (after 30 Gy and 50 Gy) during the course of RT for 22 NSCLC patients with stage I, II, or III cancer. The mean decrease in GTV was $24.7 \%$ after $30 \mathrm{~Gy}$ and $44.3 \%$ after $50 \mathrm{~Gy}$. The decrease in daily tumour volume was $1.2 \%$.

The results of a review of the role of adaptive RT for lung cancer treatment indicated that the daily regression rates in tumour volumes of NSCLCs ranges between $0.39 \%$ and $2.4 \%$ (Table 4 ). ${ }^{17}$ The results of our study indicated that GTV values decreased by $15.9 \%(7.7-41.53)$ after the fifth treatment fraction $(1500 \mathrm{cGy})$, and that the daily regression in tumour volume was $3.1 \%$. These palliative treatment results were similar to the results of other curative adaptive RT studies. 
Woodford et al. assessed three groups of 17 NSCLC patients with locally advanced-stage cancer who were separated according to the decrease in GTV. ${ }^{18}$ They suggested that adaptive planning would increase the therapeutic ratio in the first group of patients, all of whom had experienced a significant decrease in GTV. They also suggested that adaptive planning could be considered if the GTV regression exceeded $30 \%$ after the 22nd fraction for the patients in the second group, and that adaptive planning would not be beneficial in the third group of patients, who had experienced a rate of regression below 30 percent. They suggested that using resources and labour to develop an adaptive plan would be without benefit if the GTV regression did not exceed the suggested threshold value of $30 \%$.

In our study of the application of palliative thoracic RT, no statistically significant benefits were obtained using normal tissue doses. The results did reveal that there were statistically significant decreases in GTV (15\%), PTV (8\%), and field size $(5 \%)$. These changes might have occurred because our patients had large, locally advanced-stage, centrally placed tumours. The low number of patients included in our study might also have contributed to these results. Our results were consistent with the results of Woodford et al., who found that adaptive RT is not beneficial unless a threshold rate of $30 \%$ is reached or exceeded. ${ }^{18}$

In conclusion, adaptive palliative thoracic RT can be applied to NSCLC patients. The clinical implications of the results of this assessment of CT plans should be examined using prospective studies with large sample sizes and utilizing new and advanced treatment technologies.

\section{REFERENCES}

1. Halperin EC, Perez CA, Brady LW, Principles and Practice of Radiation Oncology 6th Edition. Philadelphia, Lippincott Williams \& Wilkins, 2013: 939-973.

2. Fournel $P$, Robinet $G$, Thomas $P$, et al. Randomized phase III trial of sequential chemoradiotherapy compared with concurrent chemoradiotherapy in locally advanced non-small-cell lung cancer: Groupe Lyon-Saint-Etienne d'Oncologie Thoracique-Groupe Francais de Pneumo-Cancerologie NPC 95-01 Study. J Clin Oncol 23: 5910-5917, 2005.
3. Bleehen NM, Girling DJ, Fayers PM, et al. Medical Research Council Lung Cancer Working Party. Inoperabl non-small-cell lung cancer (NSCLC): a Medical Research Council randomised trial of palliative radiotherapy with two fractions or ten fractions. Br J Cancer 63: 265-270, 1991.

4. Bleehen NM, Girling DJ, Machin D, et al. Medical Research Council Lung Cancer Working Party. A Medical Research Council (MRC) randomised trial of palliative radiotherapy with two fractions or a single fraction in patients with inoperable non-small-cell lung cancer (NSCLC) and poor performance status. Br J Cancer 1992; 65: 934-41.

5. Sundstrom S, Bremnes R, Aasebo U, et al. Hypofractionated palliative radiotherapy (17Gy per 2 fractions) in advanced nonsmall cell lung carcinoma is comparable to Standard fractionation for symptom control and survival: a national phase III trial. J Clin Oncol 22: 801-10, 2004.

6. Lester JF, MacBeth F, Toy E, Coles B. Palliative radiotherapy regimens for non-small cell lung cancer. Cochrane Database Syst Rev 1:1, 2009.

7. Rodrigues $G$, Videtic $G$, Sur R, et al. Palliative thoracic radiotherapy in lung cancer: An American Society for Radiation Oncology evidence-based clinical practice guideline. Practi Radiat Oncol 1: 60-71, 2011.

8. Guckenberger M, Richter A, Wilbert J, et al. Adaptive radiotherapy for locally advanced non-small-cell lung cancer does not underdose the microscopic disease and has the potential to increase tumor control. Int J Radiat Oncol Biol Phys 81: e275 - e282, 2011.

9. Kupelian PA, Ramsey C, Meeks SL, et al. Serial megavoltage CT imaging during external beam radiotherapy for non-smallcell lung cancer: observations on tumor regression during treatment. Int J Radiat Oncol Biol Phys 63: 1024-1028, 2005.

10. Yan D, Vicini F, Wong J, et al. Adaptive radiation therapy. Phys Med Biol 42: 123-132, 1997.

11. Ramsey CR, Langen KM, Kupelian PA, et al. A technique for adaptive image-guided helical tomotherapy for lung cancer. Int J Radiat Oncol Biol Phys 64: 1237-1244, 2006.

12. Erridge SC. Gaze MN, Price A, et al. Symptom control and quality of life in people with lung cancer: a randomised trial of two palliative radiotherapy fractionation schedules. Clin Oncol 17: 61-67, 2005.

13. Kramer GW, Wanders SL, Noordijk EM, et al. Results of the Dutch National study of the palliative effect of irradiation using two different treatment schemes for non-small cell lung cancer. J Clin Oncol 23: 2962-7290, 2005.

14. Yan D, Lockman D, Martinez A, et al. Computed Tomography Guided Management of Interfractional Patient Variation. Radiat Oncol 15: 168-179, 2005.

15. Van Zwienen M, van Beek S, Belderbos J, et al. Anatomical changes during radiotherapy of lung cancer patients. Int $\mathrm{J}$ Radiat Oncol Biol Phys 72: S111, 2008. 
International Journal of Hematology and Oncology

16. Fox J, Ford E, Redmond K, et al. Quantification of tumor volume changes during radiotherapy for non-small-cell lung cancer Int J Radiation Oncology Biol Phys 74: 341, 1999.

17. Sonke JJ, Belderbos J. Adaptive Radiotherapy for lung cancer. Semin Radiat Oncol 20: 94-106, 2010.

18. Woodford C, Yartsev S, Dar AR, et al. Adaptive radiotherapy planning on decreasing gross tumor volumes as seen on megavoltage computed tomography images. Int $\mathrm{J}$ Radiat Oncol Biol Phys 69: 1316-1322, 2007.

\section{Correspondence}

Dr. Evrim DUMAN

Antalya Eğitim ve Araştırma Hastanesi

Radyasyon Onkolojisi Kliniği

Varlık Mahallesi, Kazım Karabekir Caddesi

07100 Soğuksu,

Muratpaşa, ANTALYA / TURKEY

Tel: (+90.530) 4167578

Fax: (+90.242) 2373014

E-mail: evrimduman@hotmail.com 